\title{
COTEXTO E CONTEXTO: OS FATORES QUE COMPÓEM E CIRCUNDAM O UNIVERSO TEXTUAL
}

\author{
Cristiano Sandim Paschoal ${ }^{1}$ \\ Carlos Renê Ayres ${ }^{2}$
}

\begin{abstract}
Resumo: $\mathrm{O}$ presente artigo busca abordar o objeto teórico texto, com vistas a descrever e demonstrar os princípios básicos da Linguística Textual, bem como propiciar subsídios epistemológicos para o ensino de Língua Portuguesa que ultrapassa os limites frasais. Para tanto, iniciou-se uma reflexão sobre o percurso histórico dessa ciência que, em diferentes fases, concebeu seu objeto de maneira diversa, teórica e metodologicamente. Após, ancorando-se em princípios sociointeracionistas, são descritos os fatores que compóem e circundam o universo textual, demonstrando como os elementos discursivo-textuais se configuram em diferentes materialidades linguísticas que, por sua vez, foram utilizadas em uma prática de docência compartilhada. Ao final deste percurso teórico-metodológico, percebeu-se que o texto, sob o viés da Linguística Textual, é descrito, não somente pelo aspecto formal, mas, também, pelo discursivo, uma vez que se trata de uma ciência cujo arcabouço teórico tem como marca principal a interdisciplinaridade, tornando-se multifatorial e, por isso, imprescindível à significação textual e à sua abordagem em sala de aula.
\end{abstract}

Palavras-chave: Linguística do Texto. Cotexto. Contexto. Fatores de textualidade. Ensino de língua portuguesa.

1 Graduado em Letras Português, Espanhol e Respectivas Literaturas pela Universidade de Santa Cruz do Sul UNISC, onde, durante o período de Iniciaçáo Científica, realizou pesquisas circunscritas nos assuntos do Teto e do Discurso. Mestrando em Linguística pela Pontifícia Universidade Católica do Rio Grande do Sul, Bolsista CAPES-PROEX, realiza, atualmente, estudos que integram a perspectiva da Teoria Dialógica do Discurso, postulada pelo Círculo de Bakhtin. Membro integrante do grupo de pesquisa Tessitura: vozes em (dis)cursos (PUCCnpq) e dos projetos de investigação Ethos e ato ético: o discurso intolerante em redes (sociais) de sentidos e Alteridade, dialogismo e dialética: a constitutiva e tensa relaçâo com o outro. Parecerista ad hoc da revista Bem Legal da Universidade Federal do Rio Grande do Sul (UFRGS). E-mail: cristiano.Paschoal@edu.pucrs.br

2 Graduado em Letras Português, Inglês e Respectivas Literaturas pela Universidade de Santa Cruz do Sul, Mestre em Letras - Estudos da Linguagem pela Universidade Federal de Santa Maria e Doutor em Letras - Estudos Linguísticos também pela Universidade Federal de Santa Maria. Professor adjunto do curso de Letras da Universidade de Santa Cruz do Sul, atuando na docência nas disciplinas de Leitura e Produção de Textos, Língua Inglesa, Português Instrumental, Português Jurídico e Práticas de Ensino e Estágio Supervisionado em Língua Portuguesa e supervisionando os estágios de docência compartilhada em Língua Portuguesa no Ensino Fundamental e Médio. Atualmente, é Coordenador do curso de Letras da Universidade de Santa Cruz do Sul - UNISC. 


\title{
COTEXT AND CONTEXT: FACTORS THAT ENCOMPASS THE TEXTUAL UNIVERSE
}

\begin{abstract}
This paper aims at approaching the text theoretical object with the purpose to describe and demonstrate the basic principles of Text Linguistics, as well as provide epistemological subsides for the Portuguese Language teaching that overcomes phrasal limits. Therefore, it is important to introduce the historical path of this science, which along different phases, has conceived its object in a diverse way considering both, theory and methodology. Based on social interactionist principles, the factors that comprise and surround the text universe are described by evidencing the configuration of discursive-text elements in different linguistic materialities, which were used during a shared teaching practice. The outcomes of this theoretical-methodological course showed that the text, under the bias of Text Linguistics, is described not only through the formal aspect, but also through the discursive perspective, since it is an interdisciplinarity science that becomes multifactorial and, therefore, essential for the textual meaning and its practice in the classroom.
\end{abstract}

Keywords: Text Linguistics. Co-text. Context. Textual factors. Portuguese language teaching.

\section{Consideraçóes iniciais: do fonema ao texto}

Os estudos sobre a linguagem verbal sempre foram objeto de interesse da investigação humana. Do século XVII ao XIX, por exemplo, havia duas principais perspectivas para o estudo da linguagem: a racionalista, que a concebia como sendo uma representação do pensamento e tentava mostrar que as línguas obedeciam a princípios racionais, e a comparativa, que pregava a existência de uma língua de origem, estabelecendo um grau de parentesco entre as existentes, comparando-as e percebendo suas semelhanças gramaticais e sonoras.

Entretanto, os estudos investigativos sob a linguagem verbal foram, por muito tempo, vinculados às metodologias de outras áreas do conhecimento como, por exemplo, à Filosofia. Assim, intuindo transformar os estudos sobre a linguagem verbal em um campo científico autônomo, com métodos de análise próprios e objeto de investigação específico, tem-se, no início do século XX, mais precisamente em 1916, a publicaçáo do Curso de Linguistica Geraß ${ }^{3}$, de Ferdinand de Saussure.

$\mathrm{Na}$ tentativa de fundamentar - contrariando o enfoque histórico da época, aquilo que fazia parte dos estudos da linguagem verbal - , Saussure (1995) define a Linguística como sendo o estudo científico da língua que, por sua vez - em oposição à fala - foi caracterizada pelo linguista como sendo heterogênea, constituindo um sistema de signos linguísticos estruturados, a partir de um sistema virtual, portanto, passíveis de análise sincrônica, ou seja, no seu estado atual. Assim, definindo o objeto de estudo da linguística (a língua) e seu método de análise (o estrutural),

3 O Curso de Linguística Geral foi uma obra póstuma ao falecimento de Saussure, organizada por seus alunos Charles Bally e Albert Sechehaye, com a colaboração de A. Riedlinger. Trata-se de uma compilação de anotaçóes das aulas ministradas pelo linguista, entre 1907 a 1911, na Universidade de Genebra. 
o linguista suíço eleva o estudo científico da linguagem verbal ao status de ciênciapiloto das Ciências Humanas.

Contudo, a partir do estabelecimento da Linguística enquanto estudo científico, observa-se, durante o percurso de sua evolução, dentre suas inúmeras ramificaçôes, a existência de duas principais perspectivas epistemológicas:

\begin{abstract}
uma que se ocupa do percurso psíquico da linguagem, observando a relação entre linguagem e pensamento. Busca o que é único, universal, constante. É chamada de formalismo. Do outro lado, o sociologismo é a tendência que se aplica em estudar o percurso social, explorando a relaçáo entre linguagem e sociedade. Procura o que é múltiplo, diverso e variado. Esta divisão, que atravessa a história da Linguística, opõe os partidários de que existe uma ordem interna, própria da língua, àqueles que defendem a ideia de que essa ordem reflete a relaçáo da língua com a exterioridade, incluindo suas determinaçóes históricas e sociais. (ORLANDI, 2003, p.18, grifos da autora).
\end{abstract}

Nesse sentido, pode-se dizer que, de maneira geral, à perspectiva formalista náo interessou/interessa o uso concreto da língua por seus falantes, mas, sim, o seu funcionamento interno e sistemático. Contrária a essa perspectiva, porém sem deixar de lado as contribuiçóes dos estudos estruturalistas para o entendimento da linguagem verbal, tem-se, a partir da segunda metade do século $\mathrm{XX}$, uma visão sociologista da linguagem, resultando em um entendimento de língua como sendo uma prática social. Vinculadas a essa perspectiva, encontram-se linguísticas como a Etnolinguística, a Sociolinguística, a Pragmática, a Análise do Discurso, entre outras que, em comum, possuem como escopo não somente o intralinguístico, mas, também, o extralinguístico.

Todavia, apesar das perspectivas formalista e sociologista partirem de epistemologias opostas, ambas se preocupam com a descrição dos fenômenos linguísticos que envolvem os diferentes níveis de análise linguística (fonológico, morfológico, sintático e semântico), resultando em investigaçôes que abarcam desde os fonemas existentes em uma determinada língua aos textos que nela e por ela são criados.

Mesmo que muitas abordagens linguísticas tratem dos elementos textuais, nessa pesquisa será tratado, sumariamente, um ramo da ciência da linguagem que se caracteriza, de maneira ímpar, por apresentar em seu escopo de investigaçáo o texto como unidade de foco de análise: a Linguística Textual. Entrementes, por se acreditar que essa área de estudo pode servir como um excelente arcabouço teórico para práticas de ensino em sala de aula que envolvam o universo textual, durante a teorização, apresentam-se materialidades linguísticas que foram utilizadas em um estágio de docência compartilhada do curso Letras da Universidade de Santa Cruz do Sul, intentando servir como material de apoio a sujeitos docentes.

Para tanto, o presente artigo se organiza da seguinte forma: em um primeiro momento, relata-se um breve histórico da Linguística do Texto, apresentando suas diferentes fases e evolução no que tange às concepçóes de seu objeto; em seguida, descrevem-se os fatores que compóem e circundam o universo textual, 
demonstrando como tais elementos se configuram na materialidade linguística de diferentes gêneros textuais; por fim, fazem-se as considerações finais acerca do que foi discutido.

\section{Linguística do texto: dos estudos frasais ao evento comunicativo}

O termo Linguística Textual (doravante LT) surgiu na Europa (Alemanha), sendo empregado, inicialmente ${ }^{4}$, por Weinrich (1971). Visto que, desde seu princípio, os teóricos textuais apresentam disparidades ao conceituar o objeto texto, a Linguística Textual apresenta, em seu percurso histórico, diferentes fases que se distinguem teórica e metodologicamente.

Chamada, pela teoria, de fase Transfrástica, na primeira fase da LT podem ser encontradas orientaçôes teóricas diversas, desde estruturalistas (Weirinch) a gerativistas (Isenberg). Limitada aos aspectos frasais, na fase transfrástica apareceram estudos importantes relacionados à pronominalização, correferência, ordem de termos sintáticos, etc.

Embora se deva reconhecer que, nesse primeiro momento, deu-se um passo à frente, ao se superarem os limites da frase, e que se preparou, de certa forma, o terreno para uma gramática textual, náo se pode dizer, porém, que se tenha chegado a um tratamento autônomo do texto, nem que se tenha construído um modelo teórico capaz de garantir um tratamento homogêneo dos fenômenos pesquisados. (KOCH, 2013, p. 13).

Encontrando algumas limitações nas gramáticas frasais, uma vez que, por exemplo, um fenômeno como a correferência, muitas vezes, só pode ser descrito quando um enunciado está envolvido com outros enunciados que o circundam, surge a gramática textual.

Nessa fase, pode-se perceber bastante influência do gerativismo, que afirmava, resumidamente, que todo falante possuía competência para gerar frases e, consequentemente, textos, sendo capaz de identificar se determinada sequência de frases constituiria ou não um texto coerente. Tal competência, segundo Fávero e Koch (1998), justifica a elaboração de uma gramática textual, cujas tarefas principais seriam as seguintes:

a) verificar o que faz com que um texto seja um texto, isto é, determinar os seus princípios de constituição, os fatores responsáveis pela sua coerência, as condiçóes em que se manifesta a textualidade; b) levantar critérios para a delimitação de textos, já que a completude é uma das características essenciais do texto; c) diferenciar as várias espécies de textos. (FÁVERO; KOCH, 1998, p.14, grifos da autora).

4 Não há consenso entre os estudiosos do texto quanto ao emprego do termo linguística textual. Alguns atribuem a Cosériu (2007) a primeira utilização terminológica. Em contrapartida, muitos pesquisadores creditam a utilização do termo a Weinrich (1971), alegando que este empregou a terminologia com o sentido atual em que é empregada. 
Contudo, ainda que as gramáticas textuais tenham fornecido ao texto um tratamento autônomo - mostrando, assim, sua qualidade, em termos linguísticos, como sendo superior à frase (não em termos de extensão) - , ocorreram diversos problemas em suas formulaçóes. Um deles foi a tentativa de se traçar um percurso gerativo para o texto, quando, ao tratá-lo como um sistema finito de regras, pressupunha que o texto partisse de uma estrutura básica, desencadeando inúmeras transformações possíveis. O outro, e talvez o mais destacável, foi o fato de as gramáticas textuais separarem o texto (unidade estrutural) de discurso (unidade de uso), não analisando as manifestaçóes textuais em situaçôes reais de interação.

Logo, nesse âmbito de limitaçóes para a abordagem textual, surge o terceiro momento da Linguística Textual ligado diretamente ao advento da Pragmática, pois passa a se interessar não somente pela materialidade linguística, mas, sobretudo, por suas condiçôes de produção, ou seja, seu contexto. Intitulada de Teoria do Texto, usa-se, atualmente, o termo no plural por atrelar-se a diferentes áreas de conhecimento que estudam aspectos linguístico-textuais, envolvendo desde aspectos gramaticais e estruturais a aspectos enunciativos e pragmáticos. A seguir, apresentase uma, dentre muitas perspectivas, na qual a presente pesquisa ancora-se.

\section{Texto: um evento comunicativo}

Como dito anteriormente, há diferentes perspectivas sobre o objeto de estudo texto, inclusive dentro da própria Linguística Textual, por se caracterizar como sendo uma ciência interdisciplinar, resultando em uma gama de variaçóes conceituais, a depender do autor e da orientação teórica adotada.

Durante seu percurso histórico até os dias atuais, a LT tem como um dos seus principais desafios definir seu objeto de estudo. Em seu princípio, o texto já foi concebido de diversas maneiras, como sendo, muitas vezes, uma "unidade linguística (do sistema) superior à frase; sucessão ou combinação de frases; cadeia de pronominalizações ininterruptas; cadeia de isotopias; complexo de proposiçóes semânticas" (KOCH, 2013, p. 25).

Em contrapartida, através do advento dos estudos pragmáticos, na década de 70, o texto passou a ser concebido

pelas teorias acionais, como uma sequência de ato de fala; b. pelas vertentes cognitivistas, como um fenômeno primariamente psíquico, resultado, portanto, de processos mentais; e c. pelas orientaçôes que adotam por pressuposto a teoria da atividade verbal como parte de atividades mais globais de comunicação, que vão muito além do texto em si, já que este constitui apenas uma fase desse processo global. (KOCH, 2013, p. 26).

Diante de tantas concepçóes importantes sobre o texto, provindas de teóricos renomados como Halliday, Weirinch, Dressler, Beaugrande, entre outros, a presente pesquisa visa a contemplar os teóricos textuais brasileiros, por demonstrarem, desde o início da Linguística Textual, contribuiçôes científicas significativas para esse campo de investigação, no que concerne à língua portuguesa. 
Tais teóricos, por sua vez, compartilham, de maneira geral, da concepçáo do texto como sendo "um evento comunicativo em que convergem açóes linguísticas, sociais e cognitivas" (BEAUGRANDE apud MARCUSCHI, 2008, p. 10). Logo, visto que o presente estudo parte de uma perspectiva sociointeracionista de língua, a materialidade textual pode ser configurada como

\begin{abstract}
uma manifestação verbal constituída de elementos selecionados e ordenados pelos coenunciadores, durante a atividade verbal, de modo a permitir-lhes, na interação, não apenas a depreensão de conteúdos semânticos, em decorrência da ativação de processos e estratégias de ordem cognitiva, como também a interação (ou atuação) de acordo com práticas socioculturais. (KOCH, 2013, p. 27).
\end{abstract}

Ancorando-se, então, nesse conceito de texto, cabe destacar que, apesar de essa pesquisa reconhecer os aspectos cognitivos envolvidos na produção e reprodução textual, "a postura geral aqui adotada pode ser caracterizada como textual-discursiva na perspectiva sociointerativa, isto é, consideramos o texto em seu aspecto tanto organizacional interno como seu funcionamento do ponto de vista enunciativo" (MARCUSCHI, 2008, p. 61).

Em outras palavras, busca-se ver os aspectos linguísticos sistemáticos de construção textual e, acima de tudo, seu funcionamento histórico-social, "predominando a ideia de que o sentido se produz situadamente e que a língua é um fenômeno encorpado e não abstrato e autônomo" (MARCUSCHI, 2008, p. $60)$.

Atrelado a isso, visto que o texto, apesar de ser uma unidade de sentido que, muitas vezes, é dada por aspectos formais (léxico e morfossintaxe), seu caráter funcional é o que "fala mais alto" e, por isso, pode-se considerar até mesmo uma placa de trânsito contendo a escrita curva acentuada como sendo um texto, pois "a extensão física não interfere na noção de texto em si. Logo, o que faz um texto ser um texto é a discursividade, inteligibilidade e articulação que ele pôe em andamento" (MARCUSCHI, 2008, p. 89).

\title{
Os fatores de textualizaçáo
}

Conceituado o objeto texto, a partir da perspectiva sociointerativa na qual esse artigo se fundamenta, apresentam-se, por fim, os fatores que contribuem para a construção/elaboração de um texto escrito ${ }^{5}$. Visto que a palavra texto deriva do latim textum, que significa "tecido, textura", existem elementos que operam na produção textual, permitindo ao leitor reconstruir os sentidos estabelecidos nessa materialidade linguística. Tais elementos podem ser de natureza intralinguística, ou seja, marcados dentro do texto, ou de natureza extralinguística (elementos

5 Apesar da presente pesquisa considerar aquilo que é produzido oralmente também como texto, ater-se-á apenas ao que é escrito. 
que orbitam no contexto do texto). A seguir, serão descritos esses elementos, exemplificando-os em diferentes gêneros textuais:

\section{Fatores de cotextualidade: a coesáo e a coerência}

De maneira geral, a coesão corresponde aos elementos que contribuem para o encadeamento do texto, ou seja, seu aspecto intralinguístico, servindo de ligação coerente entre suas partes. Basicamente, há três tipologias principais de coesão textual: a referencial, que pode ser obtida por substituição ou reiteração; a recorrencial, que ocorre por recorrência de termos, de estruturas ou por paráfrases; e a sequencial, que se configura por sequenciação temporal ou por conexão.

Para que, primeiramente, os dois tipos de mecanismos linguísticos coesivos (substituição e reiteração) sejam descritos, será utilizado o texto "O cururu", de Jorge de Lima, com o intuito de demonstrar suas configuraçóes no universo textual. Trata-se de um texto que, metaforicamente, mostra as relaçôes de poder estabelecidas entre os humanos (dominador e dominado). Abaixo, segue o texto:

\section{O Cururu}

Tudo quieto, o primeiro cururu surgiu na margem, molhado, reluzente na semi-escuridão. (1) Engoliu um mosquito; baixou a cabeçorra; tragou um cascudinho; mergulhou de novo, e bum-bum! Soou uma nota soturna do concerto interrompido.

(2) Em poucos instantes, o barreiro ficou sonoro, como um convento de frades. (3)Vozes roucas, foi-não-foi, tãs-tãs, bum-buns, choros, esguelamentos finos de rás, acompanhamentos profundos de sapos, respondeiam-se. Os bichos apareciam, mergulhavam, arrastavam-se nas margens, abriam grandes círculos na flor d'água.

$[\ldots]$

(4) Daí a pouco, da bruta escuridáo, surgiram dois olhos luminosos, fosforescentes, como dois vagalumes. Um sapo cururu grelou-os e ficou deslumbrado, com os dois olhos esbugalhados, presos naquela boniteza luminosa. Os dois olhos fosforescentes aproximavam-se mais e mais, como dois pequenos holofotes na cabeça triangular da serpente. $O$ sapo náo se movia, fascinado.

(5) Sem dúvida queria fugir; previa o perigo, porque emudecera; mas já náo podia andar, imobilizado; os olhos feí́ssimos, agarrados aos olhos luminosos e bonitos como um pecado. Num bote a cabeça triangular abocanhou a boca imunda do batráquio. Ele não podia fugir àquele beijo.

A boca fina do réptil arreganhou-se desmesuradamente; envolveu o sapo até os olhos. Ele se baixava dócil entregando-se à morte tentadora, apenas agitando as patas sem provocar nenhuma reação ao sacrifício. A barriga disforme e negra desapareceu na goela dilatada da cobra. (6) E, num minuto, as perninhas do cururu lá se foram, ainda vivas, para as entranhas famélicas. O coro imenso continuava sem dar fé do que acontecia a um de seus cantores. (LIMA, 1959, p. 160, grifos nossos).

Segundo Marchuschi (2008), a coesão lexical consiste na repetição ou retomada de algum termo linguístico por hipônimos, hiperônimos e sinônimos. No enunciado 3, do texto em análise, ocorre, por exemplo, uma coesáo referencial 
por reiteraçáo, uma vez que os termos rãs e sapos são retomados pelo hiperônimo bichos. Esse tipo de relação semântica entre as palavras intitulado pela LT de cotextualidade, também pode ocorrer de maneira inversa. Caso o termo bichos aparecesse antes das palavras rãs e sapos, ter-se-ia uma relação de hiponímia, uma vez que a retomada ocorreria de um sentido mais restrito e específico.

Em relação à coesáo referencial por substituiçáo, que, de certa forma, também se trata de um mecanismo de coesão lexical, pode-se afirmar que diz respeito ao preenchimento de sentido de um termo a partir de outro elemento linguístico ou, algumas vezes, extralinguístico (contextual). Segundo Koch e Travaglia (2015), a referenciação pode ocorrer por antecipação ou retomada. No enunciado 4, temse, para exemplificação, um caso de substituição por proformas ${ }^{6}$, pois o pronome pessoal oblíquo átono os retoma a expressão dois olhos luminosos, configurandose em anáfora. É importante salientar que, quando a proforma aparece antes como, por exemplo, "Ele sempre faz a mesma coisa. Joáo não tem solução!", em que o pronome reto ele antecede o nome próprio João, denomina-se catáfora.

Há, além disso, um fenômeno denominado elipse (ou elisão) que consiste na omissão de uma palavra ou enunciado que podem ser facilmente recuperados no cotexto linguístico. No texto de Jorge Lima, pode-se encontrar já no enunciado 1 um exemplo desse recurso textual através dos verbos engoliu e mergulhou, em que a desinência número-pessoal se refere ao cururu, porém omite a repetição do termo para evitar redundância.

Além dos mecanismos coesivo-textuais, anteriormente explicados, existe uma classe de palavras que possuem um importante papel para estabelecer relaçóes de sentido entre os enunciados de um texto. Pode-se observar que no conto "O cururu" foram sublinhados alguns termos que materializam esse fenômeno.

A conjunção subordinativa como, no enunciado 2, por exemplo, estabelece uma relação de comparação entre o barreiro de sapos e um convento de frades, causando assim um efeito de sentido cômico ao texto. Também, o mesmo tipo de relaçáo estabelecida ocorre com o termo como do enunciado 4, em que dois olhos luminosos são equiparados a dois vagalumes, resultando numa tentativa de levar ao leitor uma visualização daquilo que está sendo descrito. Já no enunciado 5, ocorre o emprego da conjunçáo coordenativa porque, exprimindo a ideia de razáo (explicativa), demonstrando o motivo pelo qual o sapo emudecera, assustado com a presença da serpente. Salienta-se, ainda, que náo somente as conjunçóes sáo responsáveis pelas relaçóes existentes entre os enunciados de um texto. Tem-se, para constatação disso, a preposição para de enunciado $\mathbf{6}$ que, além de indicar uma ideia de lugar (entranhas famílicas), estabelece uma relação de dependência com o enunciado as perninhas do cururu lá se foram.

6 Trata-se de um elemento gramatical que tem a função de representar uma categoria, trazendo as marcas linguísticas do componente que substitui. Porém, possui pouca densidade sêmica. 
Cabe ainda ressaltar que, segundo a $\mathrm{NGB}^{7}$ (Nomenclatura Gramatical Brasileira), existem palavras e locuçóes que não se enquadram em nenhuma das dez classes gramaticais da língua portuguesa, classificando-as como palavras denotativas e, muitas vezes, dando-lhes pouca importância, principalmente quando presentes em manuais didáticos. Entretanto, a Linguística Textual, ancorando-se na visão semântico-discursiva do teórico Oswald Ducrot ${ }^{8}$, atenta e dá importância a esses elementos, denominados pelo linguista como sendo operadores argumentativos, demostrando sua importância no estabelecimento de sentidos entre enunciados do discurso.

Apresentados, resumidamente, os processos de coesão recorrencial e sequencial, faz-se importante descrever a coesáo recorrencial, que consiste na colocação de um item lexical no lugar de outro, servindo para que, segundo Koch e Travaglia (2015), o texto não apresente ambiguidades ou redundâncias desnecessárias. A seguir, acrescenta-se um exemplo desse processo, em que a segunda frase retoma a primeira frase inteira, através do pronome demonstrativo isso: "Flávio não organizou seu tempo para estudar para a prova de Mestrado. Isso é um absurdo!".

Entretanto, destaca-se ainda que muitos textos, principalmente os literários, abrem mão da substituição ou da recorrência justamente para a repetição criar certo efeito de sentido, como é o caso do poema "E agora José?", de Carlos Drummond de Andrade, em que a repetição da passagem "E agora José?" tem como finalidade chamar a atenção para o nome próprio José:

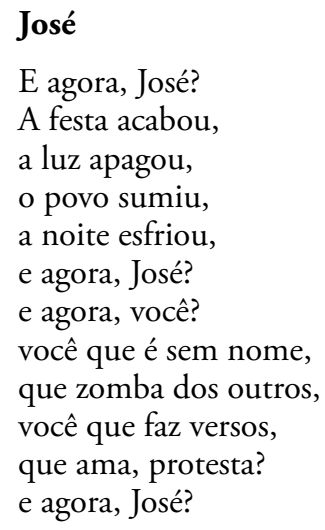

7 Em 1957, através de uma iniciativa do então Ministério da Educação e Cultura, um grupo de gramáticos estabeleceu, entre vários conteúdos gramaticais, a descrição das classes de palavras da língua portuguesa. Trata-se de um documento legal que, apesar de contribuir para os estudos linguísticos, ancora-se na perspectiva normativo-prescritiva de língua, distanciando-se, assim, da ciência Linguística que possui uma visão descritiva.

8 Vinculado ao estruturalismo saussuriano, Oswald Ducrot desenvolveu (e ainda desenvolve) estudos na área da Semântica Argumentativa. Segundo o teórico, sumariamente, a argumentação se encontra inserida na natureza da língua, principalmente nos operadores argumentativos (como, portanto, entretanto, etc) que, no discurso, evocam e direcionam o leitor para determinados sentidos. 
Está sem mulher, está sem discurso, está sem carinho, já náo pode beber, já não pode fumar, cuspir já não pode, a noite esfriou, o dia náo veio, o bonde não veio, o riso não veio, não veio a utopia e tudo acabou e tudo fugiu e tudo mofou, e agora, José?

E agora, José? Sua doce palavra, seu instante de febre, sua gula e jejum, sua biblioteca, sua lavra de ouro, seu terno de vidro, sua incoerência, seu ódio - e agora?

Com a chave na mão quer abrir a porta, não existe porta; quer morrer no mar, mas o mar secou; quer ir para Minas, Minas não há mais. José, e agora?

Se você gritasse, se você gemesse, se você tocasse a valsa vienense, se você dormisse, se você cansasse, se você morresse... Mas você não morre, você é duro, José!

Sozinho no escuro qual bicho-do-mato, sem teogonia, sem parede nua para se encostar, sem cavalo preto que fuja a galope, você marcha, José! José, para onde?

(ANDRADE, 1983 apud SANTANA, 2013) 
Observa-se que o conjunto dos mecanismos coesivos dos quais a língua dispóe dão ao texto a coerência que, por sua vez, é estabelecida na relação leitortexto-autor e diz respeito às ideias contidas em um texto de maneira ordenada e significativa. Trata-se de

construir um texto, capaz de funcionar sociocomunicativamente num contexto específico, uma operaçáo de natureza também lexical e gramatical. Quer dizer, não se pode escolher aleatoriamente as palavras nem arrumá-las de qualquer jeito; nem tampouco optar por qualquer sequência de frases. (ANTUNES, 2009, p. 93).

Como se pode depreender do trecho acima citado, a coerência está intimamente ligada à coesão textual que, por sua vez, caracteriza-se como um fator cotextual/intralinguístico. Todavia, há fatores textuais ${ }^{9}$ que não são de ordem linguística, mas discursiva, o que influencia na significação total do texto. A seguir, descrevem-se os principais elementos de ordem discursiva do universo textual, caracterizados em diferentes manifestaçóes linguísticas:

\title{
Fatores de contextualidade
}

Considerando a gama de aspectos extralinguísticos envolvidos no contrato significativo estabelecido entre o autor e o leitor de um texto, optou-se, nessa exposição, a abordagem de cinco dos principais aspectos envolvidos no universo que orbita o texto: a intertextualidade, a intencionalidade, a situacionalidade, a informatividade e a aceitabilidade.

Significando o diálogo que um texto estabelece com outros textos, a intertextualidade "é uma propriedade constitutiva de qualquer texto e o conjunto das relaçóes explícitas ou implícitas que um texto ou grupo de textos determinados mantém com outros textos" (MARCUSCHI, 2008, p. 130). A seguir, encontrase o poema de Alice Ruiz, que faz alusão e dialoga com o poema de Drummond, explicitado no item Cotextualidade deste artigo.

\author{
Drumundana \\ e agora maria? \\ o amor acabou \\ a filha casou \\ o filho mudou \\ teu homem foi pra vida \\ que tudo cria \\ a fantasia \\ que você sonhou \\ apagou \\ à luz do dia \\ e agora maria?
}

9 Atenta-se para a leitura de algumas obras contidas nas referências deste artigo por apresentarem a descrição dos fatores de ordem cognitiva envolvidos na coesão e na coerência. 
vai com as outras

vai viver

com a hipocondria

(RUIZ, 1984).

A intencionalidade, por sua vez, corresponde à capacidade de o texto produzido ser capaz de alcançar os fins comunicativos, em uma determinada situação de interlocução (comunicar, persuadir, entreter, informar, etc). Está vinculada diretamente ao produtor que possui

determinados objetivos ou propósitos, que vão desde a simples intenção de estabelecer ou manter o contato com o receptor até a de levá-lo a partilhar de suas opiniōes ou a agir ou comportar-se de determinada maneira. Assim, a intencionalidade refere-se ao modo como os emissores usam textos para perseguir e realizar suas intençóes, produzindo, para tanto, textos adequados para à obtenção dos efeitos desejados. (KOCH; TRAVAGLIA, 2015, p. 97).

Vejamos, abaixo, um texto publicitário da campanha política do candidato Tiririca que, por suas próprias palavras, não entendia nada de política e, com isso, persuadiu seus eleitores que, como forma de protesto aos outros políticos, o elegeram:

Figura 1 - Campanha publicitária eleitoral

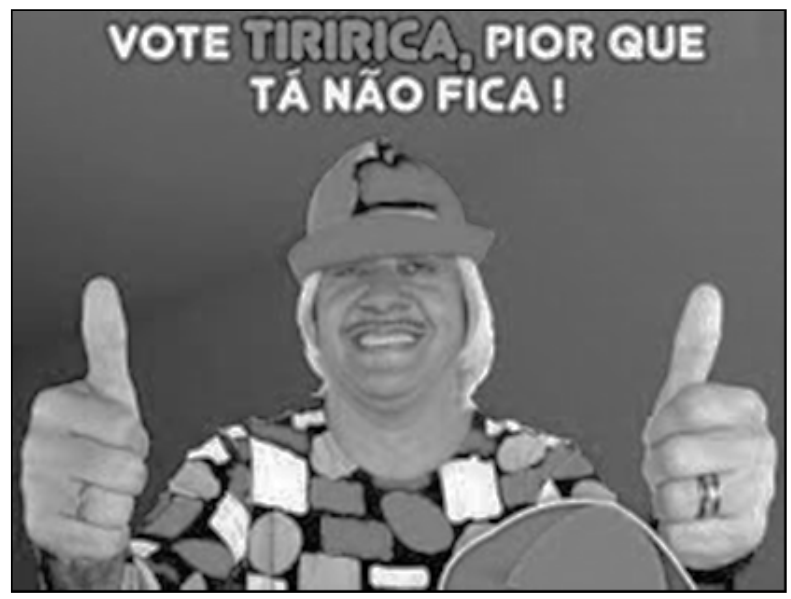

Fonte: TIRIRICA, 2012, [s/p].

Atrelada à intencionalidade, tem-se a situacionalidade, uma vez que essa representa a adequação da manifestação linguística a uma determinada situaçáo comunicativa. De fato, apesar de o progresso tecnológico disseminar os acontecimentos gerais que ocorrem no mundo inteiro, dando possibilidade de os espectadores ficarem informados, é pouco provável que um chinês, por exemplo, mesmo informado sobre o quadro político brasileiro, signifique e dê o sentido esperado a essa propaganda política tanto quanto um brasileiro. 
Além dos fatores apresentados, visto que todo texto tem a intenção de ser lido e compreendido pelo receptor, trazendo-lhe novas informaçóes, a informatividade interfere diretamente na construção da coerência de um texto, pois o desenvolvimento de tópicos referentes aos conteúdos deve ser bem elaborado, uma vez que

não se pode confundir informação com conteúdo e sentido. A informação é um tipo de conteúdo apresentado ao leitor/ouvinte, mas não é algo óbvio. Perguntar pelos conteúdos de um texto não é o mesmo que perguntar pelas informações por ele trazidas. Assim, um ato de fala não é uma informação, mas um efeito de sentido produzido que percebemos como um dos conteúdos do texto. Mas este ato de fala, por exemplo, uma ofensa ou um xingamento, não se dá de forma direta ou informativa. (MARCHUSCHI, 2008, p.132).

Também, diretamente relacionada à atitude do receptor em relação ao texto, a aceitabilidade se vincula aos fatores pragmáticos aos quais a materialidade textual está imbricada. Entretanto, salienta-se que é difícil estabelecer seus limites, uma vez que "quando duas pessoas interagem por meio da linguagem, elas se esforçam por fazer-se compreender e procuram calcular o sentido do texto do(s) interlocutore(s), partindo das pistas que ele contém e ativando seu conhecimento de mundo, da situação, etc" (KOCH; TRAVAGLIA, 2015, p. 98).

A seguir, para fins de exemplificação, mostra-se um esquema que ilustra os fatores de textualidade (cotexto e contexto) envolvidos no universo textual:

Figura 2: Fluxograma a respeito dos fatores de textualidade

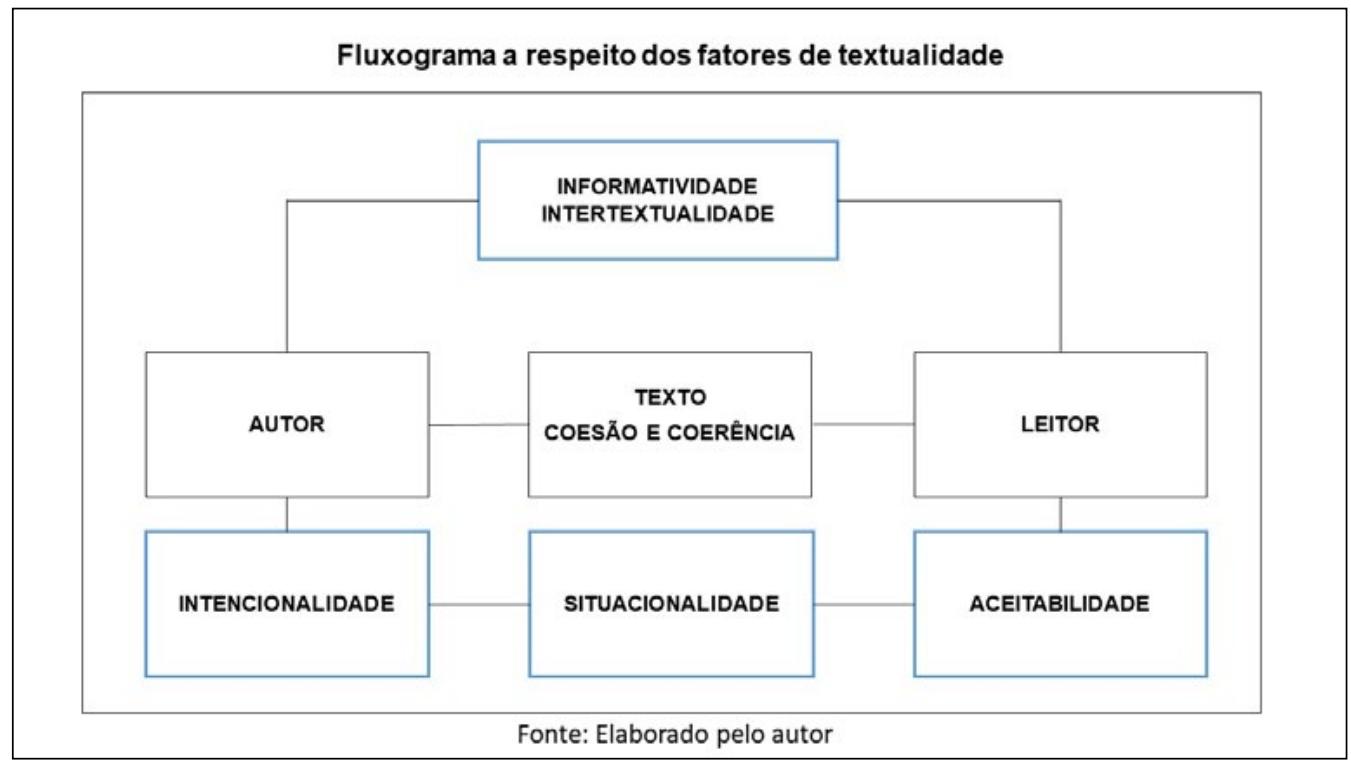

Fonte: elaborado pelos autores com base em Marcuschi (2008).

Por fim, é importante atentar para o fato de que os fatores de textualidade são apresentados muitas vezes em escolas e cursinhos de pré-vestibular, como 
sendo princípios básicos para se escrever um bom texto de tipologia dissertativa. Entretanto, há muitos textos em que não se encontram alguns critérios e, nem por isso, deixam de ter significação, uma vez que o texto "quando considerado como unidade, é uma unidade de sentido e não unidade linguística" (MARCHUSCHI, 2008, p. 97). Para fins explicativos, segue um texto literário, de gênero conto, do escritor Ricardo Ramos:

\section{Circuito fechado}

Chinelos, vaso, descarga. Pia, sabonete. Água. Escova, creme dental, água, espuma, creme de barbear, pincel, espuma, gilete, água, cortina, sabonete, água fria, água quente, toalha. Creme para cabelo, pente. Cueca, camisa, abotoaduras, calça, meias, sapatos, gravata, paletó. Carteira, níqueis, documentos, caneta, chaves, lenço. Relógio, maço de cigarros, caixa de fósforos, jornal. Mesa, cadeiras, xícara e pires, prato, bule, talheres, guardanapos. Quadros. Pasta, carro. Cigarro, fósforo. Mesa e poltrona, cadeira, cinzeiro, papéis, telefone, agenda, copo com lápis, canetas, blocos de notas, espátula, pastas, caixas de entrada, de saída, vaso com plantas, quadros, papéis, cigarro, fósforo. Bandeja, xícara pequena. Cigarro e fósforo. Papéis, telefone, relatórios, cartas, notas, vales, cheques, memorandos, bilhetes, telefone, papéis. Relógio. Mesa, cavalete, cinzeiros, cadeiras, esboços de anúncios, fotos, cigarro, fósforo, bloco de papel, caneta, projetos de filmes, xícara, cartaz, lápis, cigarro, fósforo, quadro-negro, giz, papel. Mictório, pia. Água. Táxi, mesa, toalha, cadeiras, copos, pratos, talheres, garrafa, guardanapo, xícara. Maço de cigarros, caixa de fósforos. Escova de dentes, pasta, água. Mesa e poltrona, papéis, telefone, revista, copo de papel, cigarro, fósforo, telefone interno, externo, papéis, prova de anúncio, caneta e papel, relógio, papel, pasta, cigarro, fósforo, papel e caneta, telefone, caneta e papel, telefone, papéis, folheto, xícara, jornal, cigarro, fósforo, papel e caneta. Carro. Maço de cigarros, caixa de fósforos. Paletó, gravata. Poltrona, copo, revista. Quadros. Mesa, cadeiras, pratos, talheres, copos, guardanapos. Xícaras. Cigarro e fósforo. Poltrona, livro. Cigarro e fósforo. Televisor, poltrona. Cigarro e fósforo. Abotoaduras, camisa, sapatos, meias, calça, cueca, pijama, espuma, água. Chinelos. Coberta, cama, travesseiro. (RAMOS, 1973 apud MARCUSCHI, 2008, p. 104).

$\mathrm{Na}$ tentativa de explicar que não são apenas as características linguísticas que caracterizam um texto, mas, também, as características sociocomunicativas, Marchuschi (2008, p. 104) acrescenta:

O texto de Ricardo Ramos, superficialmente visto, não acrescenta retomadas explícitas entre a sequência das sentenças. Se a estrutura do mapeamento devesse obedecer aos princípios de que as sentenças denotam fatos e sequências de sentenças denotam sequências de fatos, o texto de Ricardo Ramos só reuniria fatos isolados e não formaria uma sequência contínua nem exibiria textura (textualidade) para ser chamado de texto. Segundo Halliday/Hasan (1976), seria um não texto. Ele é todo segmentado e sem uma continuidade superficial. Mas isto não impede que funcione como um texto perfeitamente inteligível. 


\section{Consideraçóes finais}

Visto que os objetivos deste artigo, mesmo que sumariamente, foram traçar os caminhos da Linguística Textual e descrever seus princípios elementares, observouse que, a julgar pela complexidade de seu objeto teórico (o texto), vê-se uma ciência que, ao longo do tempo, foi lapidando e expandindo seu arcabouço teórico.

Primeiramente, tem-se uma passagem considerável da análise frasal para a textual, trazendo, consequentemente, a necessidade de questionamentos e perspectivas até então não feitas, resultando assim em um olhar sociointerativo para com o texto. De fato, ao serem analisados, neste artigo, os fatores intralinguísticos (cotextuais) que compóem o universo textual, percebeu-se que, através da sintaxe textual, o leitor, supostamente, pode perceber as estratégias linguísticas utilizadas pelo autor para escrever seu texto, eliminando, muitas vezes, interpretaçóes desastrosas. Além disso, os fatores contextuais, preconizados, a partir da evolução do olhar da LT, fornecem os aspectos que circundam esse universo complexo denominado texto, ampliando, assim, a capacidade, não somente do autor, mas, sobretudo do leitor para significá-lo.

Trata-se de uma ciência que possui como característica ímpar a interdisciplinaridade, alimentando-se de epistemologias diversas ${ }^{10}$ como a Morfossintaxe, a Enunciação, a Pragmática, a Análise do Discurso, e assim por diante. Além das consideraçôes feitas, a Linguística do Texto, por se mostrar uma área de estudo multifatorial, pode fornecer ricos adendos no que diz respeito à leitura, escrita e interpretação textual. Uma linguística que não só é capaz de explicar o que o texto diz, mas, também e principalmente, como ele faz para dizer.

\section{Referências}

ANDRADE, Carlos Drummond de. Antologia poética. 17. ed Rio de Janeiro: J. Olympio, 1983.

ANTUNES, I. Língua, texto e ensino: outra escola possível. São Paulo: Parábola Editorial, 2009.

COSERIU, E. Linguística del texto. Introducción a la hermenéutica del sentido. Edición, anotación y estudio previo de Óscar Loureda Lamas. Madri: Arco/Libros, 2007.

FÁVERO, L. L.; KOCH. I. Linguística Textual: introdução. 4. ed. São Paulo: Cortez, 1998.

ISENBERG, I. Cuestiones fundamentales de tipologia textual. In: BERNÁRDEZ, E. Lingüística del texto. Madrid: Arco Libros, 1987.

KOCH, I.; TRAVAGLIA, L. C. A coerência textual. 18. ed. São Paulo: Contexto, 2015.

10 Salienta-se que, na tentativa de explicar todos os fenômenos envolvidos na produção textual, a LT recorre a epistemologias que não dialogam para operacionalizar suas análises. 
KOCH, I. V. O texto e a construçáo dos sentidos. São Paulo: Contexto, 2013.

LIMA, Jorge de. Calunga. O anjo. Rio de Janeiro: Agir, 1959.

MARCUSCHI, L. A. Produção textual, análise de gêneros e compreensáo. São Paulo: Parábola Editorial, 2008.

ORLANDI, E. P. O que é linguística. São Paulo: Brasiliense, 2003.

RUIZ, Alice. Pelos pelos. São Paulo: Brasiliense, 1984.

SANTANA, A. (org). Prêmio Sesc de Poesias Carlos Drummond de Andrade. São Paulo: Ed. SESC DF, 2013.

SAUSSURE, Ferdinand de. Curso de linguística geral. Trad. Antônio Chelini, José Paulo Paes e Izidoro Blikstein. 18. ed. São Paulo: Cultrix, 1995.

TIRIRICA: pior não ficou. Carta Capital, São Paulo, 18 set. 2012. Disponível em: https://www.cartacapital.com.br/politica/tiririca-pior-nao-ficou/. Acesso em: 17 dez. 2018.

WEINRICH, H. Tempus: besprochene und erzählte Welt. 2 ed. Stuttgart Klett, 1971. 